\title{
1. TECTONIC ACCRETION AND DEFORMATION OF THE ACCRETIONARY WEDGE IN THE NORTH D'ENTRECASTEAUX RIDGE-NEW HEBRIDES ISLAND ARC COLLISION ZONE: EVIDENCE FROM MULTICHANNEL SEISMIC REFLECTION PROFILES AND LEG 134 RESULTS ${ }^{1}$
}

\author{
J.-Y. Collot, ${ }^{2}$ H.G. Greene, ${ }^{3}$ M.A. Fisher, ${ }^{3}$ and E. Geist ${ }^{3}$
}

\begin{abstract}
Drilling results from Ocean Drilling Program (ODP) Leg 134 and multichannel seismic reflection (MCS) data show the structures that develop within the North d'Entrecasteaux Ridge (NDR)-New Hebrides Island Arc (NHIA) collisional accretionary wedge, west of Espiritu Santo Island. The NDR trends east-west on the Australian plate and collides and subducts obliquely $\left(\sim 14^{\circ}\right)$ northward beneath the NHIA. This collision has produced a shallow fore-arc protrusion that culminates at the Wousi Bank. The summit area of the NDR comprises the ridge crest with adjacent terraces. Drilling at Site 828 on the northern ridge terrace revealed a pre-upper Eocene volcanic breccia overlain by a thin $(100 \mathrm{~m})$, Cenozoic, time-discontinuous, sedimentary section. Sites $827-829$, drilled at the toe of the forearc slope adjacent to the ridge, demonstrated tectonic accretion of thin (28-100 m thick) thrust sheets that consist of Pleistocene trench-fill deposits and slivers of Cenozoic ridge material including volcanic fragments. The thinness of the sediment of the NDR, as well as physical properties such as sediment instability, occurrence of low strength zones with high porosity, and water content, are responsible for frontal accretion of the thin thrust sheets.

MCS data show that a low-relief, imbricate, accretionary wedge has formed over the subducted ridge terrace, which contrasts with a high-relief accretionary wedge that developed where the ridge crest collides with the arc slope. These data also show the existence, in the accretionary wedge, of thick $(300 \mathrm{~m})$ thrust complexes that are characterized by a three-dimensional flake-like geometry and are bounded by thrusts and lateral ramps. Interpretation of drilling and MCS data suggests that the thrust complexes consist of stacked thin thrust sheets. Variation of basal friction along the décollement, possibly related to morphologic, lithologic or structural ridge complexities, may have caused the thrust complexes to develop. Although the thrusts and ramps that bound the thrust complexes may have formed during or after accretion, a sandbox experiment by Colletta et al. (1991) suggests that, during accretion, lateral variation of friction along the décollement can produce lateral ramps and thrust structures very similar in geometry to those observed in the NDR collision zone. An out-of-sequence thrust evident from drilling data and steep reverse or strike-slip faults that crosscut thrusts on MCS data indicate post-accretion deformation that develops as the accretionary wedge accommodates subduction of ridge summit asperities. This later deformation appears to extend within the subducted ridge body, suggesting that during arc-ridge collision, in addition to frontal accretion of shallow ridge sediment along the décollement, deeper parts of the ridge are being sheared off and possibly underplated. Underplating could have caused Central Espiritu Santo Island and Wousi Bank to be uplifted.
\end{abstract}

\section{INTRODUCTION}

The North d'Entrecasteaux Ridge (NDR) is part of the d'Entrecasteaux Zone (DEZ), a high relief $(2-4 \mathrm{~km})$, east-west trending set of submarine, aseismic ridges and seamounts carried on the AustraliaIndia Plate to the New Hebrides subduction zone (Fig. 1). The DEZ collides with the central part of the New Hebrides Island Arc (NHIA) in a $76^{\circ} \mathrm{E} \pm 11^{\circ}$ (Isacks et al., 1981) direction with an overall average convergence rate of $16.1 \mathrm{~cm} / \mathrm{yr}$ since $1.42 \mathrm{Ma}$ (Taylor et al., this volume). Due to the slightly oblique $\left(\sim 14^{\circ}\right)$ direction of the DEZ to the direction of convergence, the DEZ sweeps slowly northward parallel to the trench.

Previous studies (Fisher, 1986; Collot and Fisher, 1991; Fisher et al., 1991; Collot et al., 1989, 1992; Greene et al., 1992) have described the main structure and lithology of the forearc slope in the NDR collision zone, based on SeaBeam morphology, multichannel seismic reflection (MCS) data, and from diving in the French submersible Nautile. These studies have shown that the collision of the NDR has created a broad (20-30 km) and strongly uplifted forearc area that culminates at Wousi Bank (Fig. 1). A few trench-parallel folds, thrust faults, and slumps developed at the base of the arc slope in the NDR-

${ }^{1}$ Greene, H.G., Collot, J.-Y., Stokking, L.B., et al., 1994. Proc, ODP, Sci. Results, 134: College Station, TX (Ocean Drilling Program).

${ }^{2}$ ORSTOM, BP 48 , Villefranche-sur-Mer 06230, France.

${ }^{3}$ USGS, 245 Middlefield Road, Menlo Park, CA 94025 , U.S.A.
NHIA collision zone. In contrast, well developed strike-slip and normal faults extend across the arc slope along the northern and southern flanks of Wousi Bank. These transverse features are accompanied by intense mass wasting that results from the relative northward creep $(2-4 \mathrm{~cm} / \mathrm{yr})$ of the NDR along the trench during the collision (Collot and Fisher, 1991; Fisher et al., 1991). Dive results suggest that arc-slope rocks consist mainly of fractured, arc-derived rocks with highly sheared deep-water sediment that was possibly accreted at the toe of the wedge (Collot et al., 1992).

During Ocean Drilling Program (ODP) Leg 134, three sites were drilled in the NDR-NHIA collision zone to investigate tectonic accretion in such an environment. Site 828 was drilled on the NDR, and Sites 827 and 829 were drilled at the toe of the accretionary wedge east of the NDR (Figs. 1 and 2). Initial interpretations indicate that the Eocene to Holocene sedimentary cover of the NDR with fragments of its volcanic basement and trench-fill deposits are being tectonically incorporated into the toe of the NHIA slope in the form of a series of imbricate thrust sheets (Collot, Greene, Stokking, et al., 1992).

In this paper we use seismic reflection data and Leg 134 results to define the three-dimensional internal structure of the accretionary wedge produced during the collision and to determine the influence that ridge structure and mechanical properties of ridge rocks exert on the style of accretion in the NDR-NHIA collision zone.

\section{SEISMIC REFLECTION DATA}

Multichannel seismic reflection data were acquired aboard the S.P. Lee during the Australia-New Zealand-US Tripartite cruise in 1984 


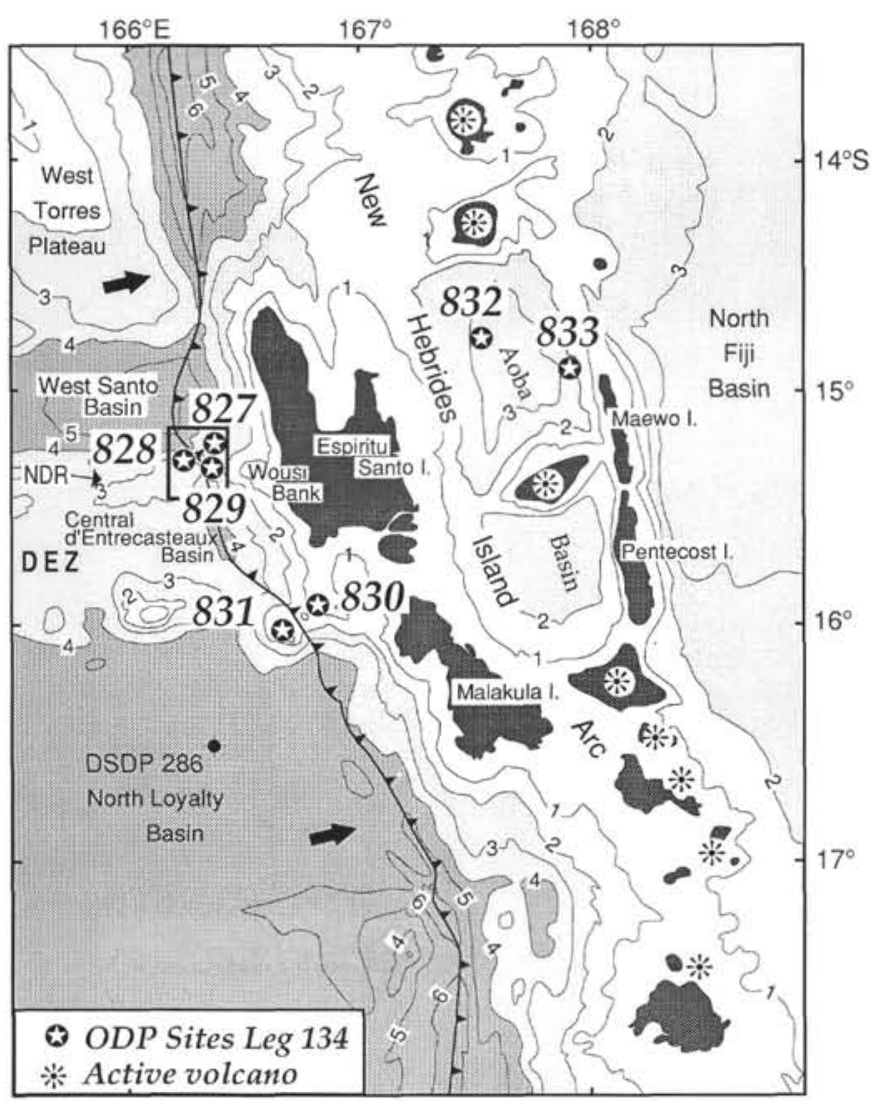

Figure 1. Leg 134 location map. The square box is the study area within the collision zone between the North d'Entrecasteaux Ridge (NDR) and the central New Hebrides Island Arc. DEZ is d'Entrecasteaux Zone. Barbed line is the trace of the interplate décollement with barbs showing downdip direction. Large arrows indicate the relative motion between the Australia-India Plate on the left and the North Fiji Basin on the right. Bathymetric contour interval is $1 \mathrm{~km}$.

and aboard the $J$. Charcot during the French MULTIPSO cruise in 1987. Seismic data obtained on the J. Charcot used a $2400-\mathrm{m}, 24-$ channel streamer with a group interval of $100 \mathrm{~m}$, and the seismic signal was generated by one Flexichoc FP 123 (trademark Geomecanique) fired every $50 \mathrm{~m}$. In the Flexichoc, an implosion causes two metal plates to strike against each other, thus producing the seismic impulse. These data were recorded using a SERCEL 338 HR digital system. Aboard the S.P. Lee, seismic data were obtained with a streamer like that used aboard the J. Charcot, but data aboard the S.P. Lee were recorded using a GUS 4200 digital system and the seismic signal was produced with a tuned array of five air guns with a total volume of $24.4 \mathrm{~L}$. The air guns provided substantially better penetration than that obtained with the Flexichoc. On the other hand, the seismic impulse created by the Flexichoc is almost free from bubble oscillation, providing a finer resolution than the air guns. All seismic sections presented in this paper were processed at the United States Geological Survey with a DISCO (trademark of Cogniseis Development) seismic data processing system. We also used single-channel seismic (SCS) data acquired and processed aboard the JOIDES Resolution during Leg 134. These data were obtained with a streamer that has a $100-\mathrm{m}-$ long active section and two $1.25 \mathrm{~L}$ water guns fired every $28 \mathrm{~m}$ (Fisher, 1992). Processing included deconvolution, bandpass filtering, and automatic gain control. All thicknesses and depths obtained from seismic reflection data are given in seconds two-way traveltime (stwt).

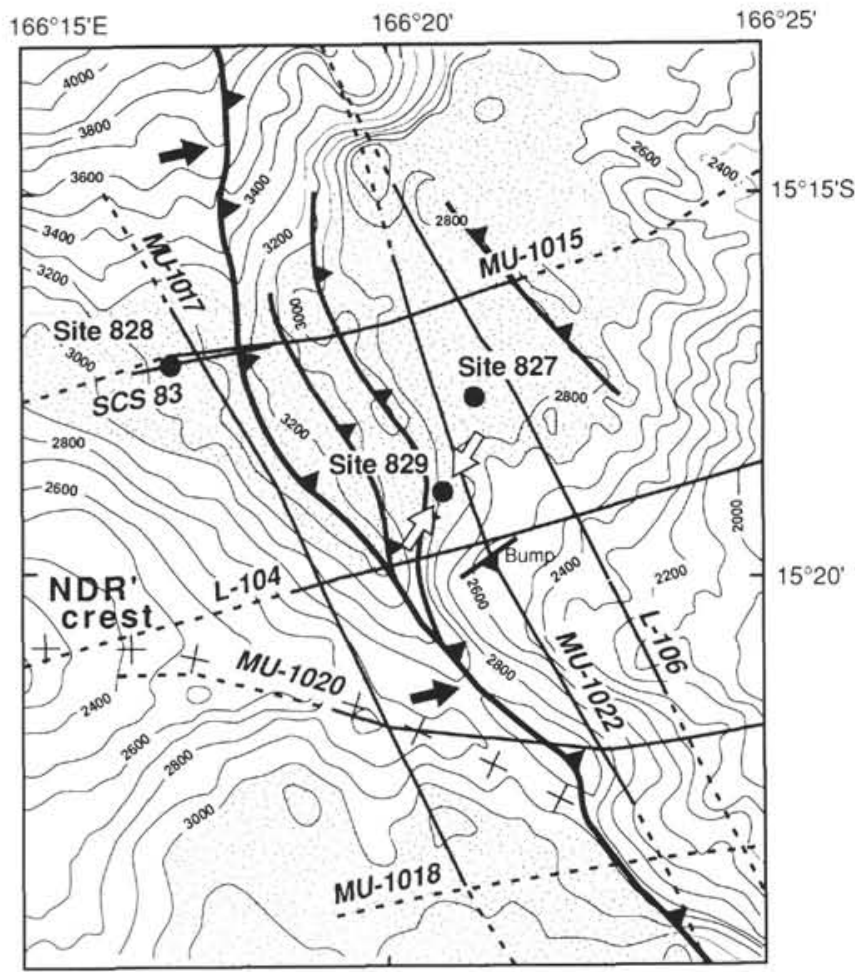

Figure 2. Simplified SeaBeam bathymetric map of the collision between the summit of the NDR and the New Hebrides Island Arc. The area is shown in Figure 1. Contour interval is $100 \mathrm{~m}$. Dotted areas represent terraces. Heavy lines indicate seismic sections shown in this report. The barbed lines indicate the trace of the interplate décollement and associated thrust faults. Crosses indicate the crest of the ridge. Black arrows indicate direction of plate convergence from Isacks et al. (1981); white arrows show direction of horizontal compressive stress obtained from BHTV data (Krammer et al., this volume).

\section{LITHOSTRATIGRAPHY AND SHALLOW STRUCTURES OF THE NDR}

\section{Lithostratigraphy of Sediment of the NDR from Site 828}

The eastern part of the NDR is topped by a narrow, elongate east-west-trending crest $(2200-2800 \mathrm{~m})$, flanked by two relatively flat terraces that are situated at a depth of $3100-3200 \mathrm{~m}$ (Fig. 2). The two holes drilled at Site 828 , on the northern terrace of the NDR, revealed that about $100 \mathrm{~m}$ of upper Eocene to Holocene fine-grained marine sediment overlie an unconsolidated volcanic breccia of possible middle Eocene age (Collot, Greene, Stokking, et al., 1992). The sediment consists of three lithostratigraphic units that recorded the transition from pelagic sedimentation during late Eocene, Oligocene (Unit III), and early Pliocene (Unit II) to hemipelagic and turbiditic sedimentation (Unit I) during Pleistocene time (Reid et al., this volume; Fig. 3). The units are separated by two major unconformities with uppermost Oligocene to Miocene and upper Pliocene to lower Pleistocene hiatuses. A minor unconformity is also identified in the uppermost Eocene strata of Unit III (Staerker, this volume).

Unit $\mathrm{I}$ is $61.9 \mathrm{~m}$ thick and consists of Pleistocene volcanic silt with calcareous silt, mixed sediment, and ooze forming the lower $10 \mathrm{~m}$ of the unit (Reid et al., this volume). In the upper $20 \mathrm{~m}$ of the unit numerous thin, sandy, and ash-rich layers are interpreted as distal parts of turbidites. Ash layers below $20 \mathrm{mbsf}$ (Coltorti et al., this volume) result from volcanic eruptions from the New Hebrides island arc volcanoes.

Unit II consists of $7 \mathrm{~m}$ of lower Pliocene soupy foraminiferal ooze. This unit is mechanically weak and may play an important role 


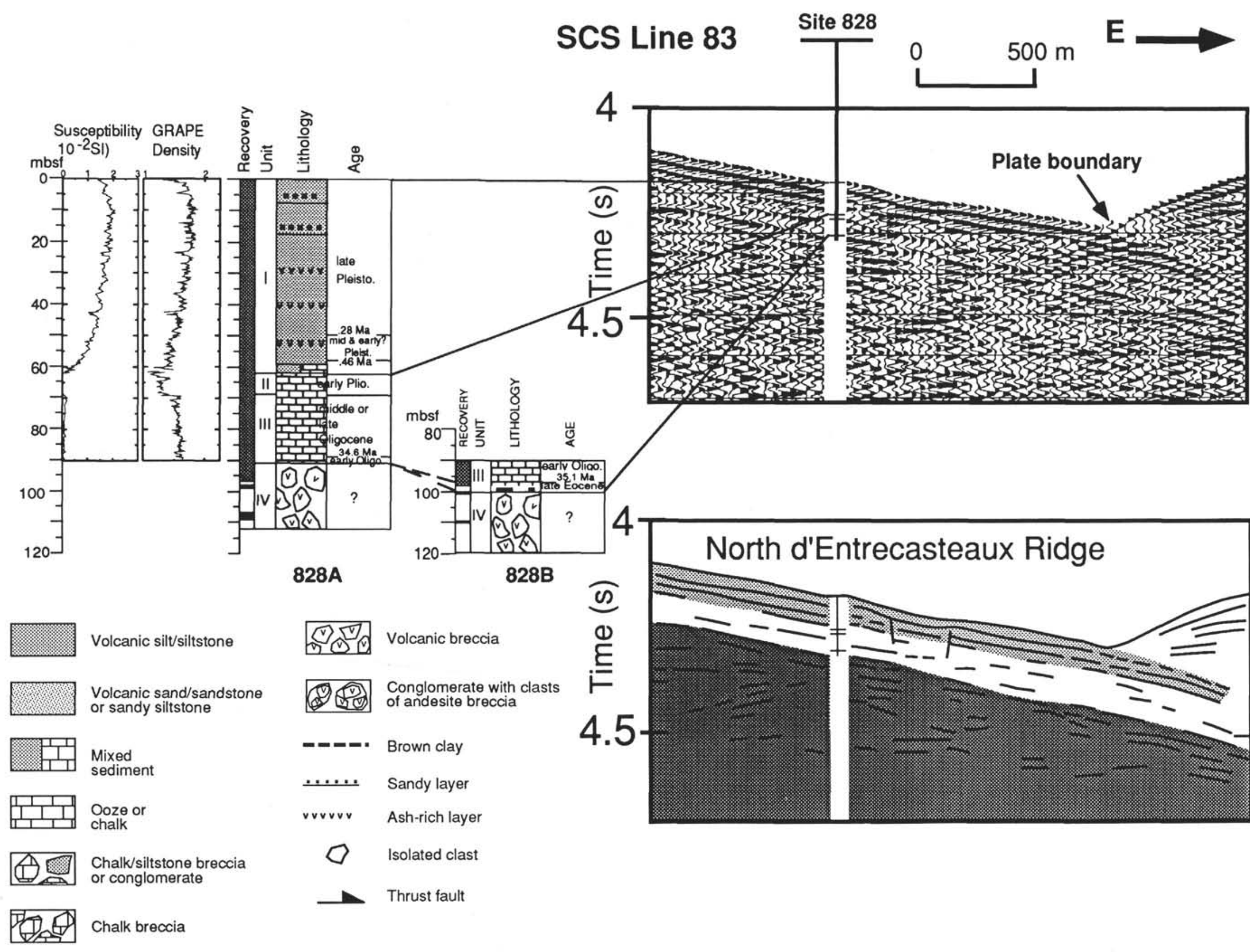

Figure 3. Single-channel seismic data and line drawing for Line 83 that crosses Site 828 on the NDR; age, lithology and physical properties of rocks recovered at Site 828 are shown on the left; location is shown in Figure 2. 
in the offscraping of ridge sediment, possibly lubricating the sole of thrust faults.

Unit III is a 21.5-m-thick-layer of lower to middle or upper Oligocene, firm nannofossil ooze overlying the volcanic basement in Hole $828 \mathrm{~A}$. In Hole $828 \mathrm{~B}$, the lower Oligocene ooze is underlain by upper Eocene ooze with brown clay laminations. Although the core recovery was $100 \%$ at Hole $828 \mathrm{~A}$, the clay and upper Eocene ooze were not found at this site, indicating that they pinch out between Holes $828 \mathrm{~A}$ and $828 \mathrm{~B}$, in turn suggesting a local unconformity and possible discontinuous sediment distribution over the ridge.

Unit IV is at least $19.4 \mathrm{~m}$ thick and consists of an altered, matrixsupported volcanic breccia in the upper level of the unit and isolated lava fragments in the lower level. Volcanic fragments include porphyritic basalts and dolerites as well as rhyolite (Coltorti et al., this volume). Geochemical data (Coltorti et al., this volume) indicate that some basaltic fragments have a typical mid-oceanic ridge basalt (MORB) geochemical affinity, whereas other basaltic clasts have affinity intermediate between MORB and island-arc tholeiite (IAT).

\section{Seismic Reflection Characteristics of the NDR}

We first present the broad seismic characteristics of the NDR from MCS data and then use SCS data and drilling information from Site 828 data to refine the shallow sedimentary structure of the northern terrace of the ridge. Fisher et al. (1991) used MCS Line L-104 (Fig. 2) to show that most of the rocks forming the NDR are non-reflective, but that locally reflective ridge rocks are present as deep as $1.5 \mathrm{stwt}$ below the seafloor. MCS Line MU-1017 extends north-northwestsouth-southeast across the ridge crest (Figs. 2 and 4) and shows highly reflective shallow strata that dip symmetrically across the north and south flanks of the ridge crest. At the crest, the sea bottom is marked by a few flat, strong reflections that overlie a shallow, poorly reflective rock body. Deeper in the section, between 4.5 and $5.0 \mathrm{stwt}$, reflective rocks, dipping mainly north, may represent the volcanic ridge basement. The attitude of the shallow strata, together with the underlying, poorly reflective rock body, suggest either that interbedded lava flows or a debris apron formed along the flanks of a submerged volcano.

On the northern terrace of the ridge, Line MU-1017 (Fig. 4) shows discontinuous strong reflections overlying a weakly reflective layer. The attitude of the strong reflections and the relatively rough, smallscale topography of the ridge terrace suggest either mass-wasting deposits or the imprint of submarine erosion.

SCS Line 83 (Fig. 3) that extends east-west across the location of Site 828 demonstrates the correlation between seismic horizons and lithostratigraphic units identified in the drill holes. Line 83 shows a group of continuous strong reflections, $0.07 \mathrm{~s}$ thick, that parallels the seafloor. This group of reflections correlates with lithostratigraphic Unit I as the subseafloor traveltime to the base of the unit is 0.08 stwt, based on an acoustic velocity of sediment of $1615 \mathrm{~m} / \mathrm{s}$ (Leonard and Ask, this volume). This correlation suggests that volcanic silt of lithostratigraphic Unit I blankets the ridge terrace. Below the strong reflections, a 0.05 -s-thick zone of faint reflections, almost acoustically transparent, appears to thicken trenchward. This zone roughly correlates with the calcareous sediment of Units II and III. Unit II cannot be directly correlated with the seismic data because the unit is too thin and its velocity is unknown. However, we use the bulk density of Unit $\Pi$ and the density-velocity relationship from Hamilton and Bachman (1982) to calculate a thickness of $0.01 \mathrm{~s}(\mathrm{v}=1510 \mathrm{~m} / \mathrm{s})$. The acoustic velocity of sediment in Unit III averages $1560 \mathrm{~m} / \mathrm{s}$ (Leonard and Ask, this volume) and the subseafloor two-way traveltime to the base of the unit is $0.13 \mathrm{~s}$. Underlying the calcareous sediment, basement rocks return discontinuous and moderately strong reflections. Along Line 83, several areas of the basement do not return seismic energy, suggesting heterogeneities within basement rocks or defocusing of seismic waves by complex structures. The top of the acoustic basement corresponds approximately to the interface between calcareous sediment and the volcanic breccia of Unit IV.

\section{MORPHOLOGY, LITHOSTRATIGRAPHY, AND STRUCTURE OF THE ACCRETIONARY WEDGE IN THE COLLISION ZONE}

\section{Morphology of the Accretionary Wedge}

SeaBeam bathymetric data in the area of Sites 827 and 829 (Fig. 2) show that the morphologies of two areas of the forearc slope are influenced by the ridge topography. One area, located east and south of Site 829 in Figure 2, exhibits a large seafloor swell with uneven morphology and a steep $\left(18^{\circ}-20^{\circ}\right)$ southwestern flank. This flank forms the tectonic front and mirrors the steepness of the adjacent northeast flank of the NDR crest. The other area extends north and west of Sites 827 and 829 and exhibits a series of flat terraces that contrasts with the large swell. The series of terraces identified in the SeaBeam bathymetric data include two large upper terraces and two narrow lower terraces that are separated by 100-m-high, trenchparallel scarps. The lower terraces appear to narrow and merge with the tectonic front south of Site 829. The scarps between these terraces were interpreted as the surface trace of thrust faults (Collot and Fisher, 1991). South of Site 829, the geometry of the thrust faults suggests either that the thrust sheets forming the lower terraces are truncated against the décollement or that the thrust sheets become buried beneath arc slope deposits. The series of terraces of the forearc slope mirror the flatness of the NDR terrace.

\section{Stratigraphy of the Lower Arc Slope in the NDR-NHIA Collision Zone from ODP Results}

The stratigraphy of the lower forearc slope in the NDR-NHIA collision zone has been documented by drilling at Sites 827 and 829 . Site 827 , located on the lower large terrace (Fig. 2) $4 \mathrm{~km}$ east of the deformation front, revealed mainly arc-slope deposits (Collot, Greene, Stokking, et al., 1992; Reid et al., this volume) and provided some evidence for accreted lower Pleistocene (Staerker, this volume) trench fill in the lower part of Hole $827 \mathrm{~B}$. In contrast, Site 829 , located at the western flank of the forearc slope swell, only $2 \mathrm{~km}$ east of the deformation front, revealed Cenozoic sediment and igneous rock fragments scraped from the NDR, as well as accreted Pleistocene trenchfill sediment.

\section{Site 827}

At Site 827 the sediment sequence was subdivided into four lithostratigraphic units (Fig. 5); no tectonic units were defined, although three major zones of brittle deformation were recognized below 140 mbsf (Meschede and Pelletier, this volume). These zones show a locally well defined reverse sense of movement and display a scaly fabric and intense faulting with dip angles of $60^{\circ}-80^{\circ}$.

The upper part ( $0-140 \mathrm{mbsf})$ of the sediment sequence recovered at Site 827 consists of upper Pleistocene volcanic silt with normally graded sand beds (lithostratigraphic Unit I) overlying middle Pleistocene volcanic silt devoid of sandy layers (lithostratigraphic Unit II) (Fig. 5). These undeformed sediments are interpreted as hemipelagic deposits interbedded with arc-derived distal turbidites deposited in a slope basin (Reid et al., this volume).

The lower part ( $<140 \mathrm{mbsf}$ ) of Site 827 includes highly deformed upper Pliocene to lower Pleistocene siltstone and sandstone with intervals of breccia and conglomerate (lithostratigraphic Unit III), all of which overlie an undated sed-lithic breccia (lithostratigraphic Unit IV). In lithostratigraphic Unit III, the various clasts of coral, upper Pliocene siltstone, lower and middle Eocene chalk, highly lithified sedimentary rocks, and andesite suggest that this unit is trench fill or forearc slope deposits comprised of debris derived from both the arc and the downgoing plate (Reid et al., this volume; Staerker, this volume). Near 250 mbsf, a biostratigraphic inversion associated with a well developed 20 -m-thick interval of rock showing scaly fabric is evidence for the thrusting of upper Pliocene rocks over lower Pleis- 


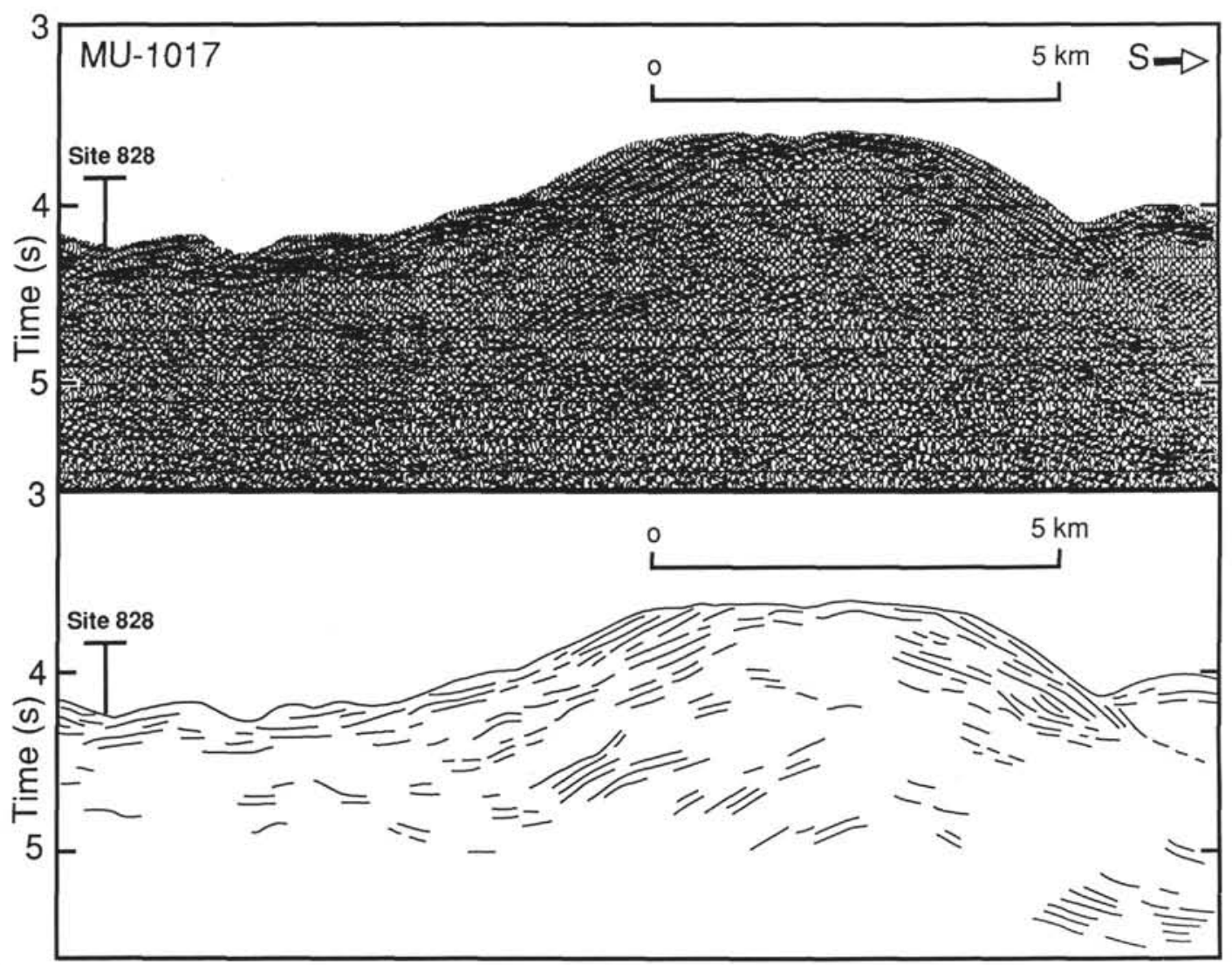

Figure 4. Migrated multichannel seismic reflection data and line drawing for section MU-1017 that cuts across the North d'Entrecasteaux Ridge; location is shown in Figure 2.

tocene rocks (Staerker, this volume). This thrusting suggests that sediment of the lower part of lithostratigraphic Unit III is accreted trench fill. The upper part of this unit, which is highly sheared, may also be accreted trench fill or underthrust forearc slope deposits. The sed-lithic breccia of lithostratigraphic Unit IV contains clasts of andesite breccia and volcanic siltstone and sandstone. Based on the calc-alkaline magmatic affinity of amphiboles found in the andesite clasts, these clasts are thought to originate from Espiritu Santo Island (Coltorti et al., this volume) and the sed-lithic breccia is interpreted as a debris flow of arc material that accumulated at the base of the forearc slope and was subsequently accreted to the wedge (Reid et al., this volume).

\section{Site 829}

At Site 829 rocks were subdivided into 16 lithostratigraphic units and 9 tectonic units (A to I in Fig. 5), separated by major thrust zones. These units were identified primarily on the basis of repeated biostratigraphic inversions, changes in lithologies, structural deformation, and well-log correlation, specifically from the Formation MicroScanner (FMS) (Staerker; Reid et al.; Meschede and Pelletier; Chabernaud et al., all this volume). Major thrust zones are described either as levels of brittle deformation with highly brecciated rocks exhibiting a reverse sense of movement, as found at the base of tectonic Unit C, or as levels of ductile deformation with shear bands, microshear folds, and planar fabric, as documented at the bases of tectonic Units D, F, and H. Most major thrust faults are associated with an upper Eocene chalk interval and brown clay laminations that are similar to the upper Eocene firm ooze and brown clay recovered at Site 828 near the top ( $100 \mathrm{mbsf}$ ) of the volcanic breccia (Fig. 3). FMS data collected between 70 and 467 mbsf show that the major shear zones are characterized by sediment with high electrical conductivity and are associated with borehole enlargement (Chabernaud, this volume). Based on lithology and age analyses, the tectonic units are interpreted to represent different sheets of accreted ridge material and/or trench fill.

Tectonic Units B, C, G, and $\mathrm{H}$ are thought to represent accreted trench fill because they consist of deformed Pleistocene volcanic silt, siltstone, siltstone-chalk breccia, and sandstone or conglomerate, which all contain numerous clasts and debris derived either from the ridge or island arc. Arc-derived material incorporated into trench fill includes Pliocene and lower Miocene chalk clasts and contorted lower Pliocene chalk layers. Ridge-derived material includes Oligocene chalk clasts (Staerker, this volume). Although Reid et al. (this volume) suggest that the Pliocene chalk clasts are possibly derived from the ridge because lower Pliocene foraminiferal ooze was recovered at Site 828 on the ridge, Staerker (this volume) argues that this ooze could not be transported as coherent clasts because of its soupy nature when deposited. We believe that the ridge's ooze may have been squeezed and lithified into chalk during accretion, thus providing a source for the Pliocene chalk clasts found in the trench fill.

Tectonic Units $\mathrm{E}$ and $\mathrm{F}$ are interpreted as rock sheets made up of slivers of ridge calcareous sediment overlain by trench fill. These rock sheets were scraped off the ridge above the volcanic breccia at the brown clay horizon (Reid et al., this volume). In these units the ridge rocks consist of upper Eocene and Oligocene chalk (lithostratigraphic Units X and XII) and the trench fill comprises Pleistocene mixed sediment and silty chalk (lithostratigraphic Units IX and XI). A lower Pliocene chalk layer (lithostratigraphic Unit VIII) was deposited above Pleistocene trench fill and may represent a slump or an olistolith.

Tectonic Unit D represents a sheet of NDR volcanic breccia and calcareous sediment overlain by trench fill. Clasts of basalt, pyroxenite and serpentinite were recovered from the volcanic breccia (lithostratigraphic Unit VII). The basalt clasts display a MORB/IAT transitional affinity similar to that of the basalt recovered at the base of Site 828 (Coltorti et al., this volume), suggesting that the section was 


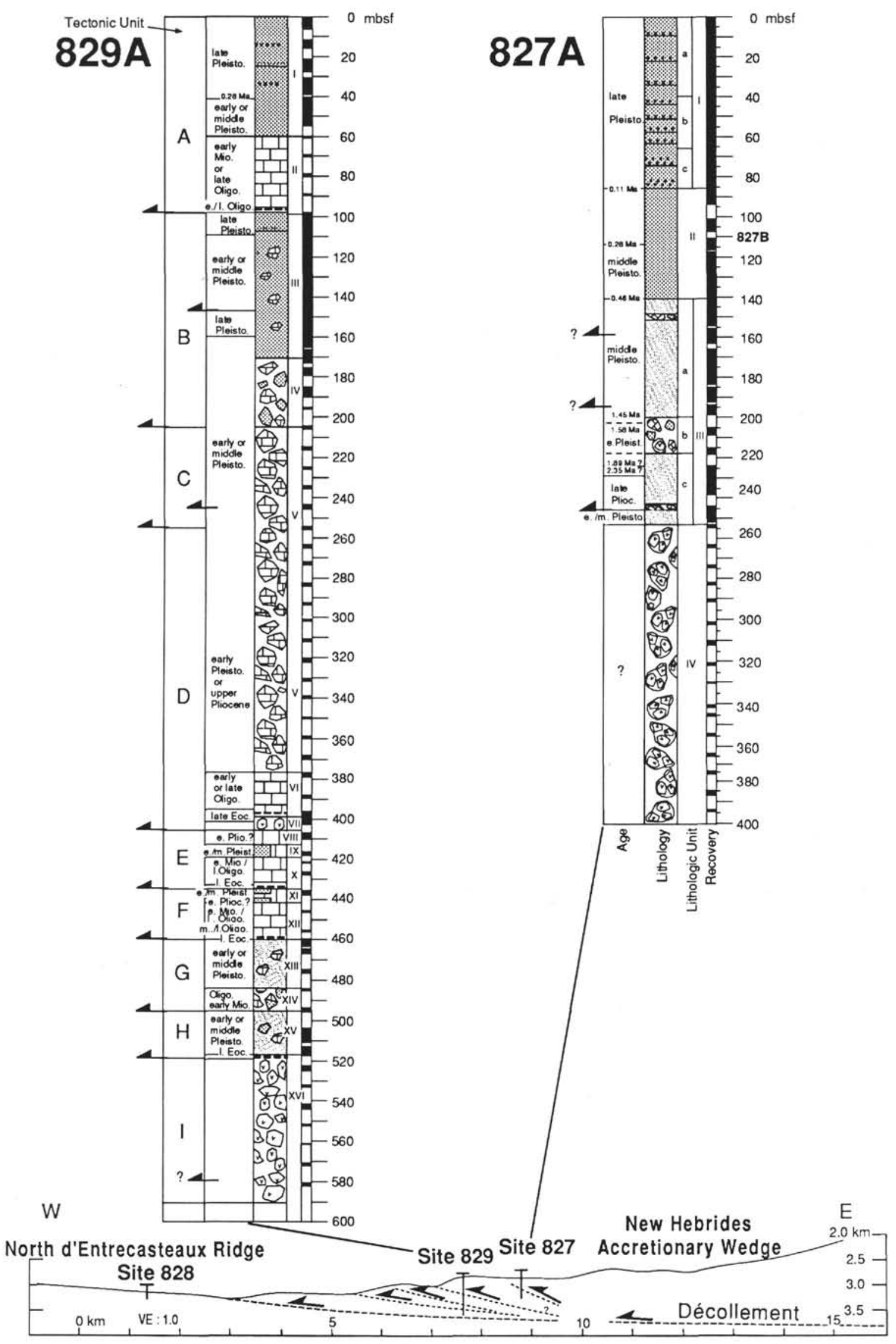

Figure 5. Lithostratigraphy for Sites 827 and 829 after Reid et al. (this volume); ages are from Staerker (this volume) and tectonic units from Meschede and Pelletier (this volume). See Figure 3 for keys to lithology; VE = vertical exaggeration. 
sheared off within the upper part of the ridge basement, which includes a similar unconsolidated volcanic breccia. As on the ridge, the accreted volcanic breccia is overlain by upper Eocene chalk with brown clay laminations and middle or upper Oligocene chalk (lithostratigraphic Unit VI). Trench fill deposits (lithostratigraphic Unit V) consist of sheared Pleistocene siltstone-chalk breccia with upper Oligocene or lower Miocene chalk clasts.

Tectonic Unit I represents an accreted sheet of the volcanic and calcareous sediment of the NDR separated from the overlying trench fill (tectonic Unit $\mathrm{H}$ ) by a major thrust zone. The volcanic breccia (lithostratigraphic Unit XVI) is highly sheared and includes clasts of basalt, diabase, microgabbro, and gabbro (Coltorti et al., this volume). This volcanic breccia is interpreted to be accreted from the ridge basement because the igneous clasts found in the breccia show rare-earthelement patterns and $\mathrm{Pb}$ isotopic signatures very similar to those of the igneous rocks from Site 828, which show MORB/IAT transitional affinity (Coltorti et al., this volume). The upper part of the accreted volcanic breccia includes a thin section of the upper Eocene chalk with brown clay laminations, similar to those found on the ridge.

Tectonic Unit A may either represent a sliver of accreted NDR sediment draped by an in-situ slope volcanic deposit or include a 45-m-thick slump block. Pleistocene volcanic silt in the upper part of tectonic Unit A (lithostratigraphic Unit I) and on the NDR are similar in composition, making it difficult to recognize offscraped-ridge Pleistocene material (Staerker, this volume). However, Reid et al. (this volume) suggest that the section of glass-rich volcanic silt below 10 mbsf at Site 829 was accreted from the ridge because similar glass-rich layers occur at Site 828 , but not at Site 827 . The origin of the upper Oligocene or lower Miocene chalk of lithostratigraphic Unit II is problematic because this age interval is represented by an unconformity at Site 828; coeval sediments at DSDP Site 286 (Fig. 1) consists of deep-water clays and those on Espiritu Santo Island consist of volcanic breccia with shallow-water carbonate. The tectonic contact at the base of tectonic Unit A is inferred from poorly preserved, minor reverse faults. The brown clay found at the base of other major shear zones and on the ridge was also recovered near the base of tectonic Unit A, but is of Oligocene age in contrast to a late Eocene age for the ridge clay. Staerker (this volume) suggests that the upper Oligocene or lower Miocene chalk could represent an open-marine facies of the Espiritu Santo Island shallow-carbonate rocks and that this chalk might represent a 45-m-thick slump block emplaced within Pleistocene sediment. Alternatively, if the absence of Oligocene brown clay and upper Oligocene or lower Miocene chalk at Site 828 results from a fault or a local unconformity, and if the clay and chalk are present elsewhere on the ridge, then this clay and chalk could have been accreted from the ridge. Localized unconformities or faults probably occur on the ridge as suggested by the upper Eocene sediment that appears to pinch out between Holes 828A and 828B (Fig. 3).

\section{Seismic Structure of the Accretionary Wedge}

A three-dimensional image of the internal structure of the accretionary wedge in the NDR collision zone is obtained from a coarse grid of MCS lines that have been processed including migration (Fig. 2). We first discuss MCS Lines MU-1015, L-104, and MU-1020 that are perpendicular to the deformation front because they are critical to locating the décollement and imaging the different rock units that were recognized at Sites 827 or 829 . We then examine the lateral structural variations of the accretionary wedge using MCS Lines MU-1022 and L-106 that trend parallel to the deformation front, thus providing a tie between the other MCS lines.

\section{Line $M U-1015$}

Seismic reflection Line MU-1015 shows the structures that are associated with the underthrusting of the northern terrace of the NDR beneath the region of flat terraces, opposite the NDR, on the accretionary wedge (Figs. 2 and 6). On the left (western) part of the line, the initial collision and underthrusting of the ridge may be associated with incipient thrusting of shallow ridge sediment as indicated by a sinuous attitude and disruption of the ridge strata beneath the deformation front of the wedge. However, the attitude of the ridge strata could be influenced by slumping along the forearc slope, as suggested by seismic reflection and morphologic data, which together indicate that a rock mass with a lobate shape and a acoustically well defined base exists across the tectonic front.

The interplate décollement that separates accreted material from subducting sediment does not produce strong, continuous reflections on Line MU-1015. However, the décollement ( $D_{1}$ in Fig. 6) is marked locally as a dip discordance between west-dipping or flat reflections of the subducted ridge strata and east-dipping reflections within the overlying accretionary wedge. The décollement can be traced toward the eastern part of the line by connecting scattered reflections of similar dip discordance. Hence, Line MU-1015 indicates that the ridge terrace extends under the wedge with an apparent undulating topography.

Eastward within the accretionary wedge, the apparent east dip of reflections become steeper, and below Site 827 steeply east-dipping reflections may be confused with poorly-migrated diffractions. On average, the apparent dip of the reflections decreases from top to bottom of the wedge. Dip discordances within the wedge appear to separate packages of coherent reflections with similar attitudes. West of the projection of Site 829 , a package of undulating and slightly eastdipping reflections appears to be gently folded, whereas between Sites 829 and 827 another package of reflections consistently dips steeply eastward. We propose that the packages of east-dipping reflectors are bounded by imbricate thrust faults (Fig. 6). One of these faults is associated with the scarp that offsets the seafloor between the wide and narrow terraces (Fig. 2). This association suggests recent displacement along this fault.

The east-dipping reflections diminish in amplitude and disappear beneath the lower part of the wedge, indicating the presence of an accreted, unstratified, poorly sorted or tectonized rock body. This body could be interpreted as deformed accreted trench-fill.

Beneath the strongly reflective seafloor in the area of Sites 827 and 829 nonreflective rocks overlie the stacked thrust sheets, suggesting the presence of poorly-sorted slope deposits. Thus seismic data of Line MU-1015 supports Site 829 and 827 drilling results, which indicate arc-slope deposits overlying tectonically accreted sediment.

\section{Line L-104}

Seismic reflection Line L-104 extends northeast along the crest of the NDR and shows the structures of the accretionary wedge beneath the seafloor swell (Fig. 2). Stacked thrust sheets similar to those interpreted from Line MU-1015 are not readily evident on this line (Fig. 7). Seismic reflections within the wedge appear to be pulled up and distorted because of the steep seafloor topography over the swell of the forearc slope. However, part of this distortion might be real and due to the rough topography of the underlying ridge segment. Fisher et al. (1991) suggest that the décollement emerges at the toe of the arc slope along the strong reflections forming Reflector $\mathrm{D}_{2}$ and that the décollement extends arcward along these reflections because they supposedly mark a prominent angular discordance between overlying wedge rocks and underlying rocks of the subducted ridge. At the toe of the arc slope, Reflector $D_{2}$ appears to truncate underlying apparent west-dipping reflections, indicating that this reflector could be the décollement (Fig. 7). Above Reflector $\mathrm{D}_{2}$, flat reflection $\mathrm{A}$ can be traced discontinuously westward to a seafloor break and is interpreted as a thrust fault, suggesting that tectonically accreted rocks may lie above Reflector $\mathrm{D}_{2}$.

Site 829 was projected into Line L-104 in order to investigate the cause of Reflector $\mathrm{D}_{2}$ and to locate the décollement. We used acoustic velocities obtained from physical properties measurements and sonic $\log$ data to convert the depth dimension to traveltime. The orthogonal projection of Site 829 ( $\mathrm{P}$ in Fig. 7) provides a minimum subsea-level 

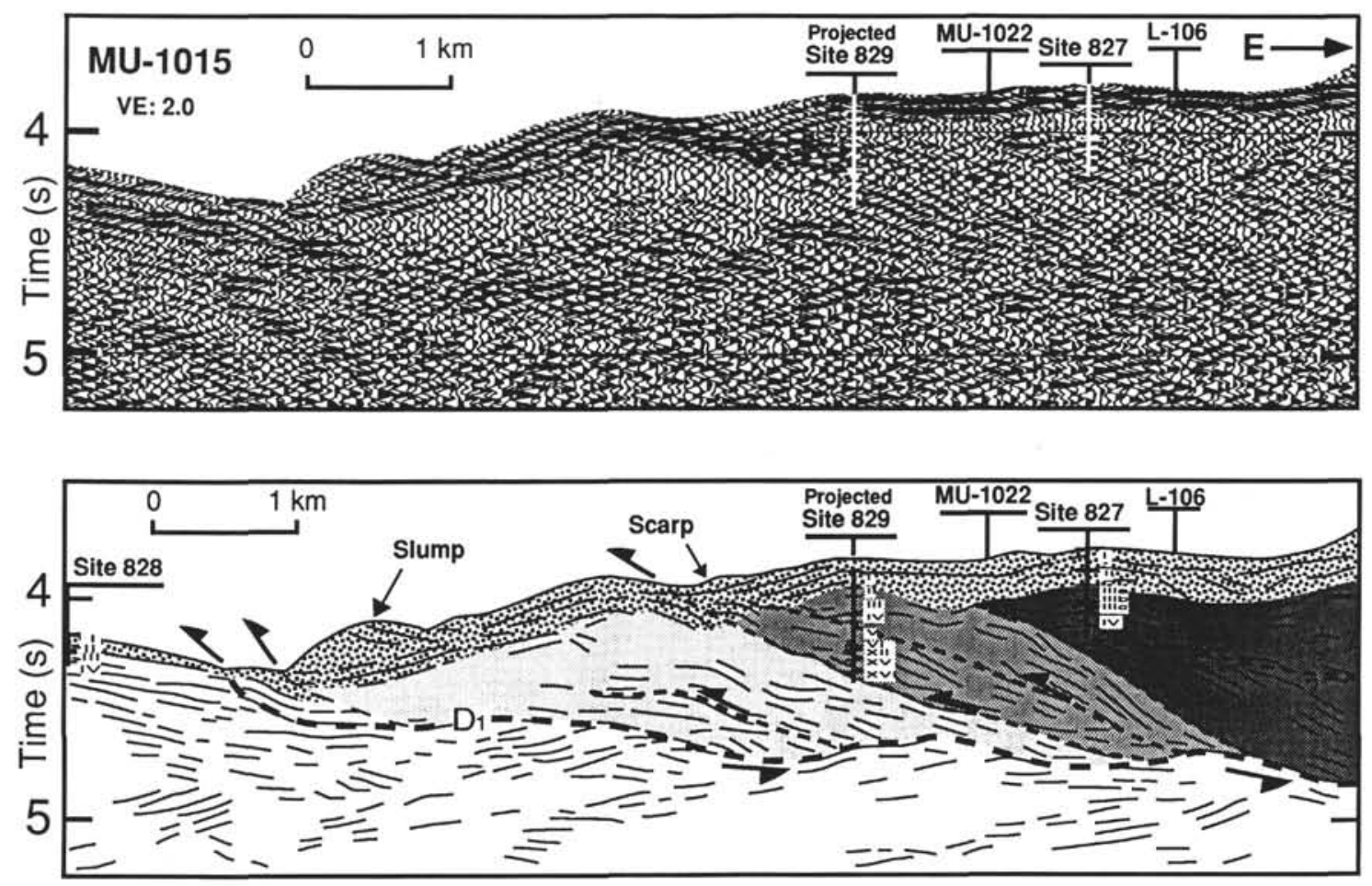

Figure 6. Migrated multichannel seismic reflection data and line drawing for part of section MU-1015 that cuts across the low-relief, collisional accretionary wedge of the New Hebrides Island Arc. $D_{1}$ is interpreted as the interplate décollement. Heavy dotted area indicates slope deposits; gray shades indicate imbricated accreted trench fill and ridge material; roman numerals on projected ODP sites refer to lithostratigraphic units indicated in Figure 5.

traveltime of $4.05 \mathrm{~s}$ for the total depth of Hole $829 \mathrm{~B}$, indicating that the volcanic breccia of lithostratigraphic Unit XVI might correlate with Reflector $\mathrm{D}_{2}$ and therefore with the décollement. This correlation would suggest that drilling at Site 829 possibly entered the upper part of the décollement.

\section{Line $M U-1020$}

This line extends east-west along the crest of the ridge, crosses the deformation front, and follows a depression transverse to the lower arc slope (Fig. 2). Based on SeaBeam morphology and single-channel seismic reflection data, the accretionary wedge in this depression appears to be deformed by east-west-trending faults that result from the collapse of the arc slope, in the wake of the NDR (Collot and Fisher, 1991). These faults that trend almost parallel to Line MU-1020 may obscure the structures along the line. Wedge sediment overlying Reflector A (Fig. 8) is characterized by reflections that dip mostly trenchward and terminate downward against Reflector A. This geometry suggests that the trenchward-dipping sediment is derived from upslope. The interplate décollement is not clearly defined on Line MU-1020. Strong reflections from the sediment that drape the ridge can be traced discontinuously eastward beneath the toe of the forearc for only about $2 \mathrm{~km}$ (Reflector $\mathrm{D}_{2}$ in Fig. 8). These reflections, which show minor folding beneath a slumped feature, may indicate the location of the interplate décollement. Above these reflections, Reflector A extends arcward for about $5 \mathrm{~km}$ from close to the base of the wedge. This reflector and overlying sediment are disturbed by high-angle faults with small offsets, suggesting that the décollement might lie deeper than Reflector A.

\section{Line $M U-1022$}

Seismic Line MU-1022 shows the along-strike structures of the accretionary wedge and the shape of the subducted part of the NDR
(Fig. 9). This line crosses southward over the wide arc terrace and the slope swell (Fig. 2). The roof of the subducted part of the ridge, that is also interpreted as the décollement, is inferred at three places along the line from the locations of this roof identified on crossing MCS lines. The shape of the underlying ridge is characterized by a flat and a high that are similar to the terrace and crest of the unsubducted part of the ridge, as shown by the comparison between the geometry of horizon $\mathrm{D}_{2}$ in Line MU 1022 and topography on Line MU-1017 (Fig. 4).

Beneath the slope swell, a body of highly reflective strata appears to cap the subducted ridge crest. These strata are separated from overlying nonreflective sediment by Reflector $D_{2}$ that is offset vertically by branching, reverse faults near the crossing of Line L-104. On an unpublished detailed SeaBeam map, this set of faults is associated with an elongate seafloor bump trending north $55^{\circ} \mathrm{E}$ across the deformation front, attesting to recent activity of a possible reverse or transpressive fault zone ("bump" in Fig. 2). These faults pierce the subducted ridge crest, indicating that Reflector $\mathrm{D}_{2}$ might not be the interplate décollement. North of these faults, Reflector $\mathrm{D}_{2}$ deepens and becomes discontinuous.

Beneath the terrace flat in Line MU-1022, a few distinct reflections show divergent shallow dips either to the north or south. These horizons define lenticular rock bodies that are either nonreflective or return incoherent reflections. These rock bodies may represent transverse sections of trenchward-dipping sedimentary successions resulting from mass-wasting along the accretionary wedge front, similar to those described by Fisher et al. (1991) north and south of Wousi Bank. However, crossing Line MU-1015, together with drilling results at both Sites 827 and 829 , indicate that these lenticular rock bodies represent longitudinal sections of imbricate thrust sheets. Thus, the horizons that bound the lenticular bodies belong to east-dipping thrust planes. In addition to thrust faults, high-angle faults disrupt shallow slope sediment and deform underlying accreted rocks as shown on the left part of Line MU-1022. 


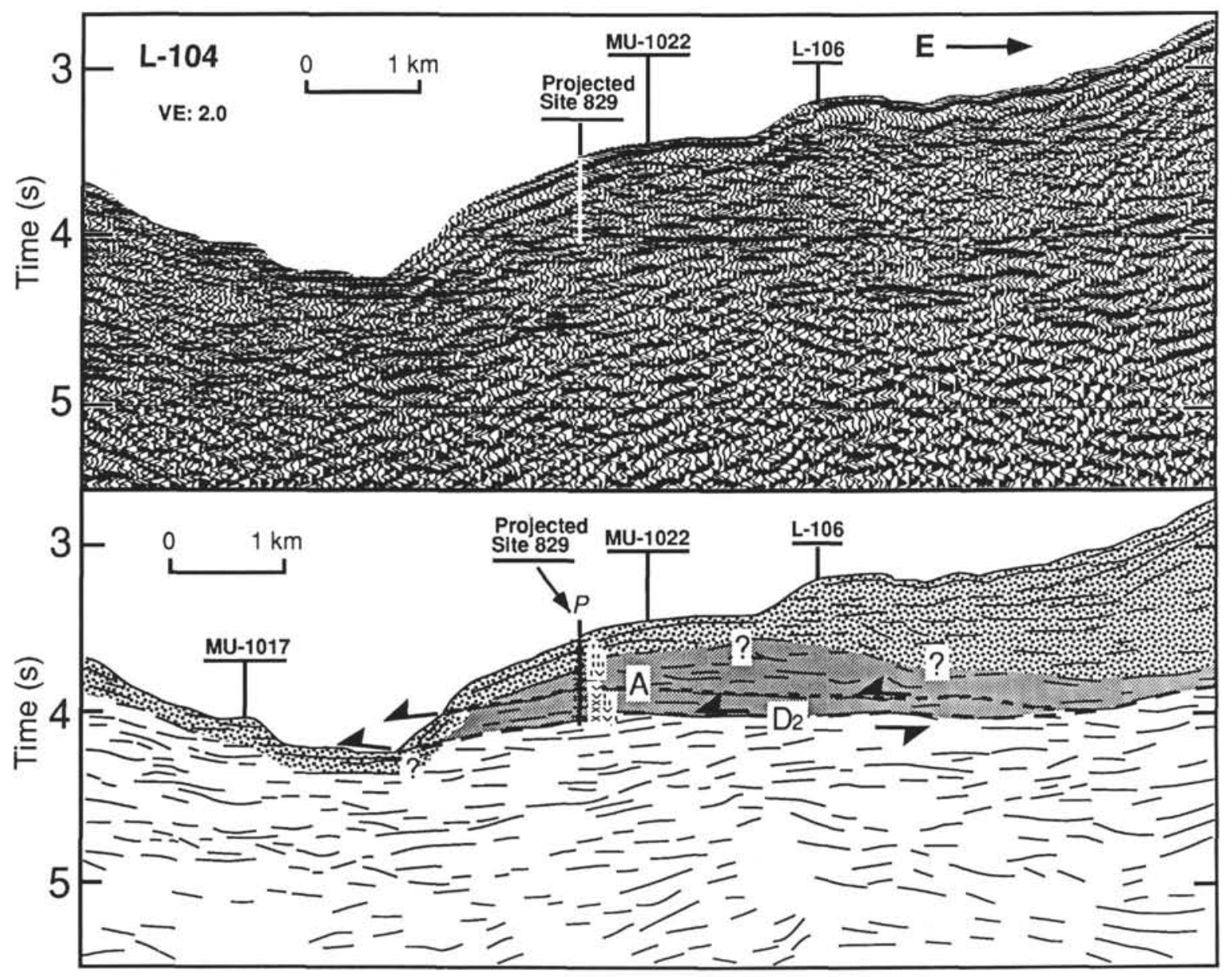

Figure 7. Migrated multichannel seismic reflection data and line drawing for part of section L-104 that cuts across the high-relief, collisional accretionary wedge of the New Hebrides Island Arc. Heavy dotted area indicates slope deposits; gray shades indicate imbricated accreted trench fill and ridge material; $\mathrm{D}_{2}$ is interpreted as the interplate décollement; ODP Site 829 has been projected $1400 \mathrm{~m}$ onto L-104 perpendicular to the line; roman numerals on projected ODP Site 829 refer to lithostratigraphic units indicated in Figure 5.

\section{Line L-106}

Seismic Line L-106 shows along-strike structures of the forearc slope, 1-2 km farther east of the deformation shown in Line MU-1022. Line L-106 (Fig. 10) was shot with a stronger seismic source than that used for Line MU-1022, providing a clearer image of the deep structures of the accretionary wedge and underlying ridge, as well as delineating areas of low-frequency coherent reflections from zones of incoherent reflections and bands of high-frequency reflections.

Areas of low-frequency coherent reflections beneath Reflector A are attributed to ridge rock underlying the wedge, as suggested by crossing MCS lines and interpretations of Fisher et al. (1991). These ridge rocks show an internal dip discordance $\left(\right.$ Reflector $\left.\mathrm{D}_{2}\right)$ that coincides with the décollement interpreted on Line L-104 (Fig. 7), suggesting that the rock bodies between Reflectors $A$ and $D_{2}$ are accreted thrust sheets and that these sheets can be as thin as 100-150 m. Moreover, beneath the slope swell, on top of Reflector A, a small $(1 \mathrm{~km})$ feature ( $\mathrm{F}$ in Fig. 10) returns continuous short reflectors, suggesting a stack of three or four 30-m-thick layers. These layers may represent thin imbricate thrust sheets similar to those drilled in the lower part of Site 829 (tectonic Units E-H in Fig. 5) and may form a small duplex. Alternatively, the short reflectors my indicate stratified layers that are fault bounded.

Zones of incoherent reflections extend above Reflector A, mainly south of crossing Line L-104 and beneath the seafloor terrace, where a few discontinuous reflections with divergent dips cut across a zone of incoherent reflections. This geometry defines weakly reflective, lenticular rock bodies analogous to those observed on Line MU-1022. Hence, these horizons are interpreted to be thrust planes that deform wedge material.

Bands of high-frequency reflections crosscut seismic Line L-106 and dip generally south within rocks underlying the seafloor swell in the 4-5 stwt interval. The bands form in distinct zones and mark sharp changes in the dip as well as vertical offset of the low-frequency reflections. These bands suggest that low-angle faults such as fault $T$ in Figure 10 and high-angle faults deform accreted units and pierce the underlying ridge crest, indicating that Reflector $\mathrm{D}_{2}$ might not be the present-day décollement.

\section{DISCUSSION}

The structures produced in the accretionary wedge east of where the bulk of the NDR intersects the arc slope differ from structures produced in the accretionary wedge immediately north and south of the NDR. MCS data from Fisher et al. (1991) show that the interplate décollement follows the top of the subducting West Santo and Central d'Entrecasteaux Basin fills (Fig. 1), suggesting that offscraping of basin fill is not presently occurring. At these locations, mass-wasting deposits from the NHIA forearc slope make up most of the accretionary wedge (Fisher et al., 1991). In contrast, where the summit of the NDR collides with the arc slope, MCS data collected in the vicinity of Sites 827 and 829 , and drilling results demonstrate offscraping of ridge and 


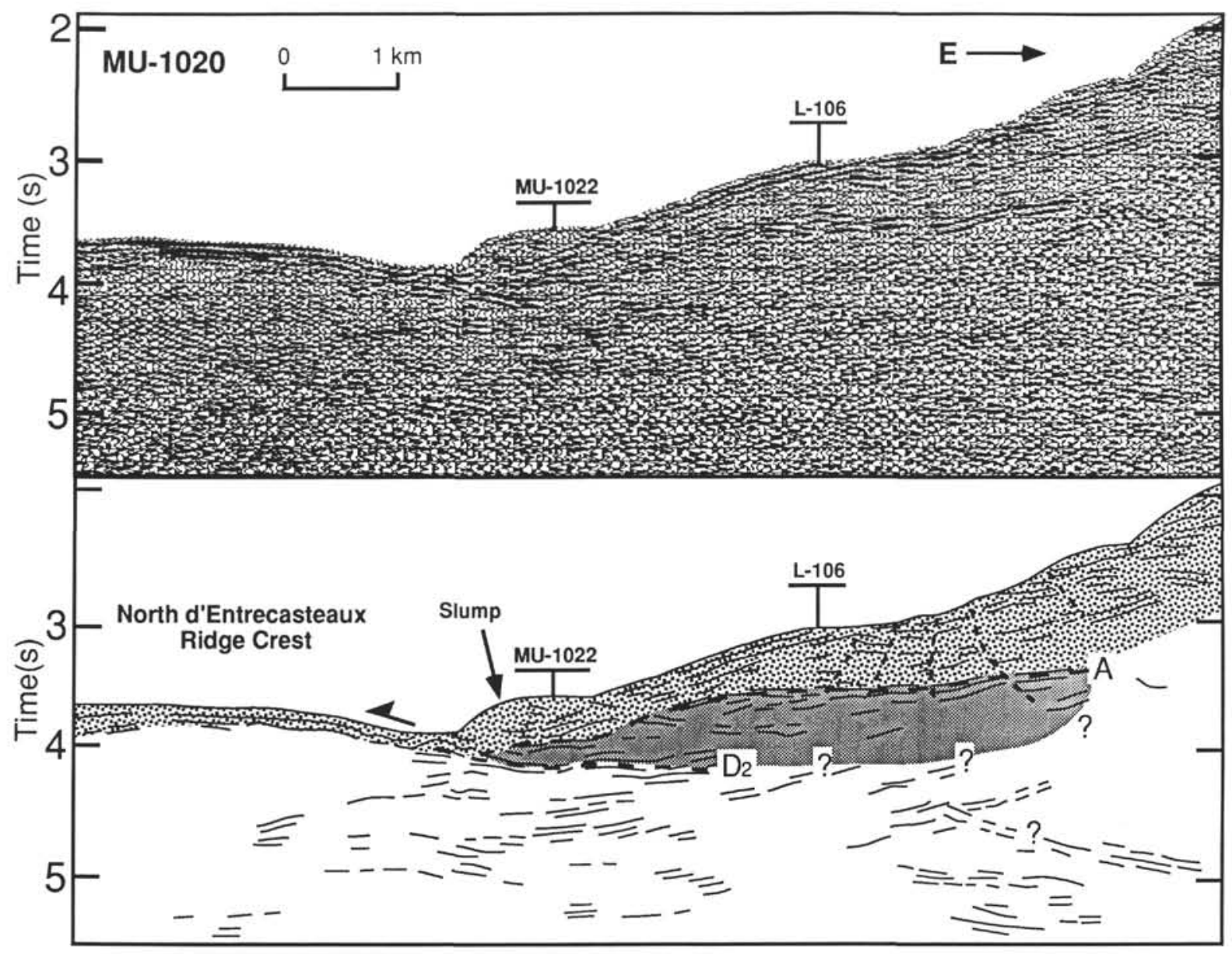

Figure 8. Migrated multichannel seismic reflection data and line drawing for part of section MU-1020 that extends along the NDR crest and cuts across the high-relief, collisional accretionary wedge of the New Hebrides Island Arc. Heavy dotted area indicates slope deposits. Reflector $A$ and $D_{2}$ are discussed in the text.

trench-fill sediment, which are progressively accreted at the deformation front of the accretionary wedge. However, MCS data reveal an important along-strike variation in the geometry of the accretionary wedge structures and in the reflectivity of accreted rocks, as well as an uncertainty as to the location of the interplate décollement. In the following sections we discuss and interpret the different structural geometries, the types of accreted sediment and the location of the décollement as they apply to formation and deformation of a ridge-arc collisional accretionary wedge. We then analyze the physical properties of ridge sediment and their implications for the style of accretion.

\section{Collisional Fore Arc Structures}

\section{Accretionary Wedge Structure Beneath the Slope Terrace}

A low-relief, imbricate structural fan (Boyer and Elliott, 1982) has formed from moderately reflective rocks where the northern terrace of the NDR underthrusts the slope terraces. In the direction perpendicular to the strike of the trench, this fan consists of stacked, seismically defined, 3-5 km long thrust sheets with lensoidal or "flake-shaped" cross sections that average individually $300 \mathrm{~m}$ in thickness (Fig. 6). The east-dipping thrust faults that bound the thrust sheets rejoin locally across-strike of the trench and merge with the décollement. The dip angle and direction of shear zones that separate the thrust sheets cored on Leg 134 are in good agreement with the attitude of the east-dipping reflections within the accretionary wedge. For example, at Site 829 well developed shear zones dip north-east at $15^{\circ}-65^{\circ}$, based on both FMS data (Chabernaud, this volume) and structural observations of cores oriented by paleomagnetism (Collot, Greene, Stokking, et al., 1992). The dip angle of the shear zones decreases downhole from about $60^{\circ}$ at the base of lithostratigraphic Unit IV (200 mbsf) to $15^{\circ}$ near the top of lithostratigraphic Unit XVI (530 mbsf) (Meschede and Pelletier, this volume). These data are consistent with the borehole televiewer (BHTV) data, which indicate a main dip direction of the structures of $80^{\circ} \mathrm{E}$ between 166 and $374 \mathrm{mbsf}$ (Krammer et al., this volume). In the trench-parallel direction, the imbricate thrust sheets also have flake-like 3- to 5-km-long cross sections, and are bounded above and below by gentle north- and south-dipping roof and floor thrusts that rejoin along the strike of the trench (Figs. 9 and 10). FMS data (Chabernaud, this volume) indicate north- and south-dipping thrusts within accreted rocks. Between 259 and 453 mbsf, several structures dipping north west at $30^{\circ}-50^{\circ}$ and north at $35^{\circ}-60^{\circ}$ were detected by FMS and could be associated with north dips of the thrusts interpreted from seismic reflection data. South-dipping thrusts are exemplified by the major thrust fault near $259 \mathrm{mbsf}$ (Fig. 5) that dips south-southeast at $45^{\circ}-55^{\circ}$. Hence, beneath the forearc seafloor terraces, the imbricate thrust sheets are noncylindrical and their three dimensional geometry is that of a thin $(300 \mathrm{~m})$ lens or flake with equal length and width and completely bounded by thrust planes.

The imbricate fan and overlying slope sediment are also deformed by high-angle faults that are transverse to the arc slope (Fig. 9). These faults are correlated with the $60^{\circ}-80^{\circ}$ dips of the faults and scaly fabric horizons that were measured in cores at Sites 827 and 829.

Seismic and ODP drilling data indicate that thrust sheets with nonreflective internal structure consist primarily of accreted trench-fill 

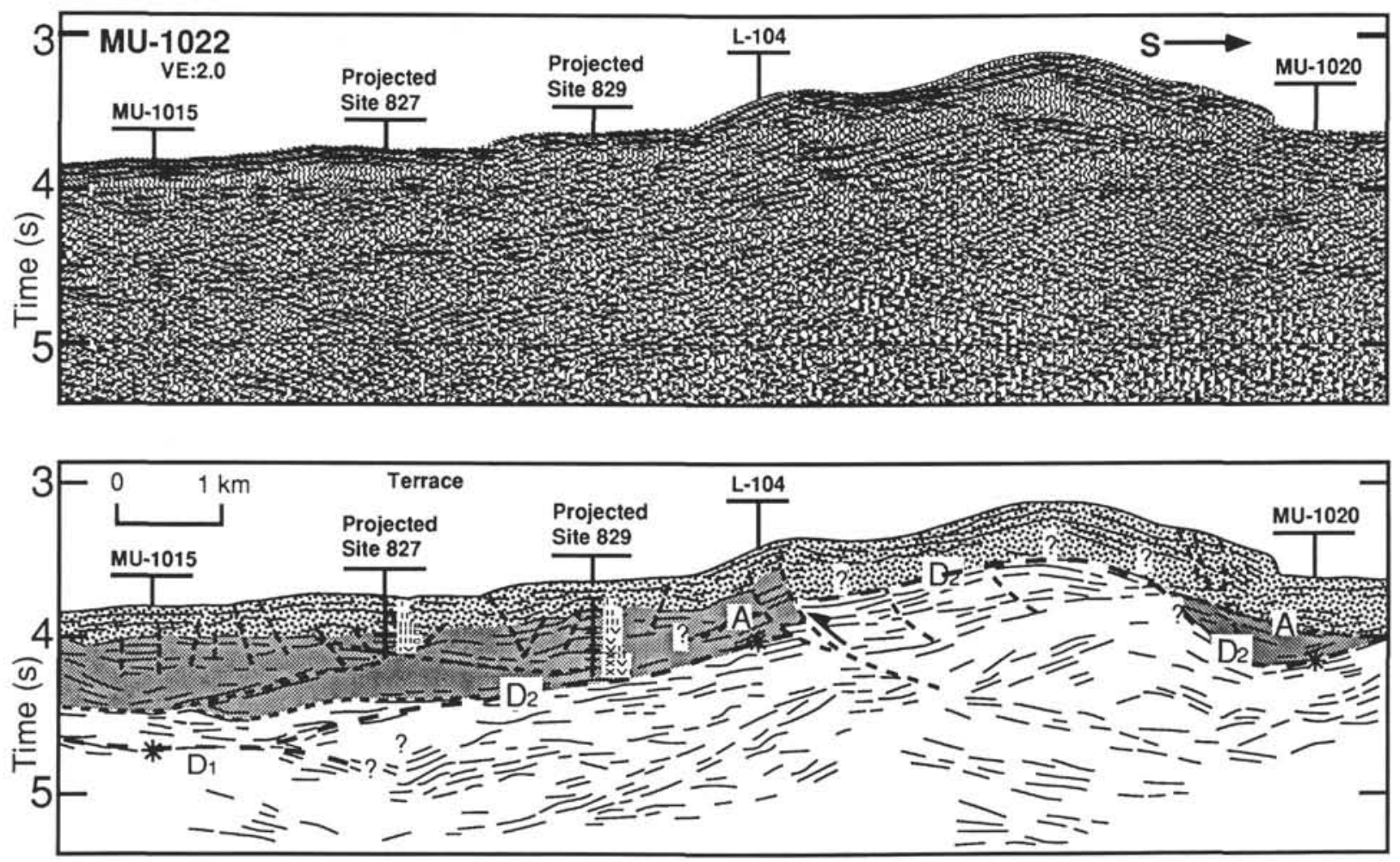

Figure 9. Migrated multichannel seismic reflection data and line drawing for part of section MU-1022 that cuts along the strike of the accretionary wedge in the collision zone between the NDR and the New Hebrides Island Arc. Location is in Figure 2. Stars are the locations of the roof of the subducted NDR from crossing MCS lines. Reflectors $\mathrm{D}_{1}$ and $\mathrm{D}_{2}$ are discussed in the text; other dashed lines are thrusts and faults; heavy dotted area indicates forearc slope deposits; gray area indicates accreted trench fill and ridge material.

deposits, whereas thrust sheets that return east-dipping coherent reflections include both accreted trench-fill and ridge sediment. The eastdipping reflections within some thrust sheets image lithologic boundaries that are either depositional or structural in nature. Depositional boundaries would indicate that the thrust sheets are 300 -m-thick accreted lithostratigraphic sequences. Alternatively, the coherent reflections within a thrust sheet could image structural boundaries, suggesting that thrust faulting has thickened the accreted rocks during the collision process. Site 829 results were instrumental in showing that the east-dipping reflections are mainly structural boundaries. Although Site 829 is located $5 \mathrm{~km}$ south of Line MU-1015, we projected Site 829 onto this line because of the homogeneous seismic characteristics of the accretionary wedge along Line MU-1022 between Site 829 and Line MU-1015 (Figs. 2 and 9). Site 829 penetrated a suite of nine thin thrust sheets with contrasting lithologies (Fig. 5). The four upper thrust sheets (tectonic Units A to D) and the next four below these (tectonic Units $\mathrm{E}$ to $\mathrm{H}$ ) average $100 \mathrm{~m}$ and $28 \mathrm{~m}$ thicknesses, respectively, contrasting with the average $300-\mathrm{m}$ thickness measured from seismic data. Therefore, we suggest that the reflective, thick $(300 \mathrm{~m})$ thrust sheets that we have termed thrust complexes or thrust duplexes, could have formed by thrusting or stacking of the thin primary thrust sheets during or after tectonic accretion.

Seismic and biostratigraphic data from Site 829 support postaccretion deformation in the accretionary wedge. In an accretionary wedge formed by seaward verging thrust faults, thrust sheets identified deeper in the drill hole should be progressively younger. However, this age progression can be reversed when the wedge growth is controlled or complicated by landward verging thrust faults, out-ofsequence accretionary process or large slumps. At Site 829, late Pleistocene age sediment was found only in the two upper thrust sheets (tectonic Units A, B; Fig. 5), indicating that they were emplaced within the last $0.28 \mathrm{Ma}$, whereas the youngest sediment recovered from the deeper thrust sheets (tectonic Units C to I) were early to middle Pleistocene (1.6-0.28 Ma) in age, providing a maximum age for their emplacement (Staerker, this volume). Thus, the two upper thrust sheets were emplaced after the lower ones. However, seismic reflection and structural data from reoriented cores do not provide evidence for landward verging shear zones at the base of tectonic Units A and B. The contact between tectonic Units A and B shows very scarce evidences of shear, whereas the base of tectonic Unit B is marked by a major thrust zone of northeast to east dip direction (Meschede and Pelletier, this volume). Tectonic Unit A is interpreted either as a slump structure (Staerker; Meschede and Pelletier, all this volume) or as an accreted sliver of the NDR (Reid et al., this volume), and tectonic Unit B is either accreted trench-fill or sheared slope deposits (Staerker, this volume). Based on these observations we speculate that tectonic Unit A resulted of post-accretion emplacement of slump material or out-of-sequence thrusting and that tectonic Unit B was emplaced by an out-of-sequence thrusting process.

\section{Accretionary Wedge Structure Beneath the Slope Swell}

A high-relief, structural wedge comprising reflective and nonreflective rocks has formed where the crest of the NDR underthrusts the slope swell. These rocks include tectonically accreted rocks and arc-slope sediment organized in a fashion that differs from a classical imbricate structural fan, in the sense that this wedge is deformed by steep faults transverse to the arc slope. Near Site 829 , moderately reflective, accreted sediment recognized above Reflector $D_{2}$ on Line MU-1022 (Fig. 9) appear to be truncated southward against a steep reverse or transpressive fault zone. South of this fault zone, the sharp change from moderately to nonreflective sediment above Reflector $D_{2}$ suggests that the deformation front consists mainly of arc-slope sediment because this sediment has seismic characteristics similar to that of the slope sediment recovered in the upper section of Site 827. Higher along the arc slope, seismic interpretation of Line L-106 (Fig. 

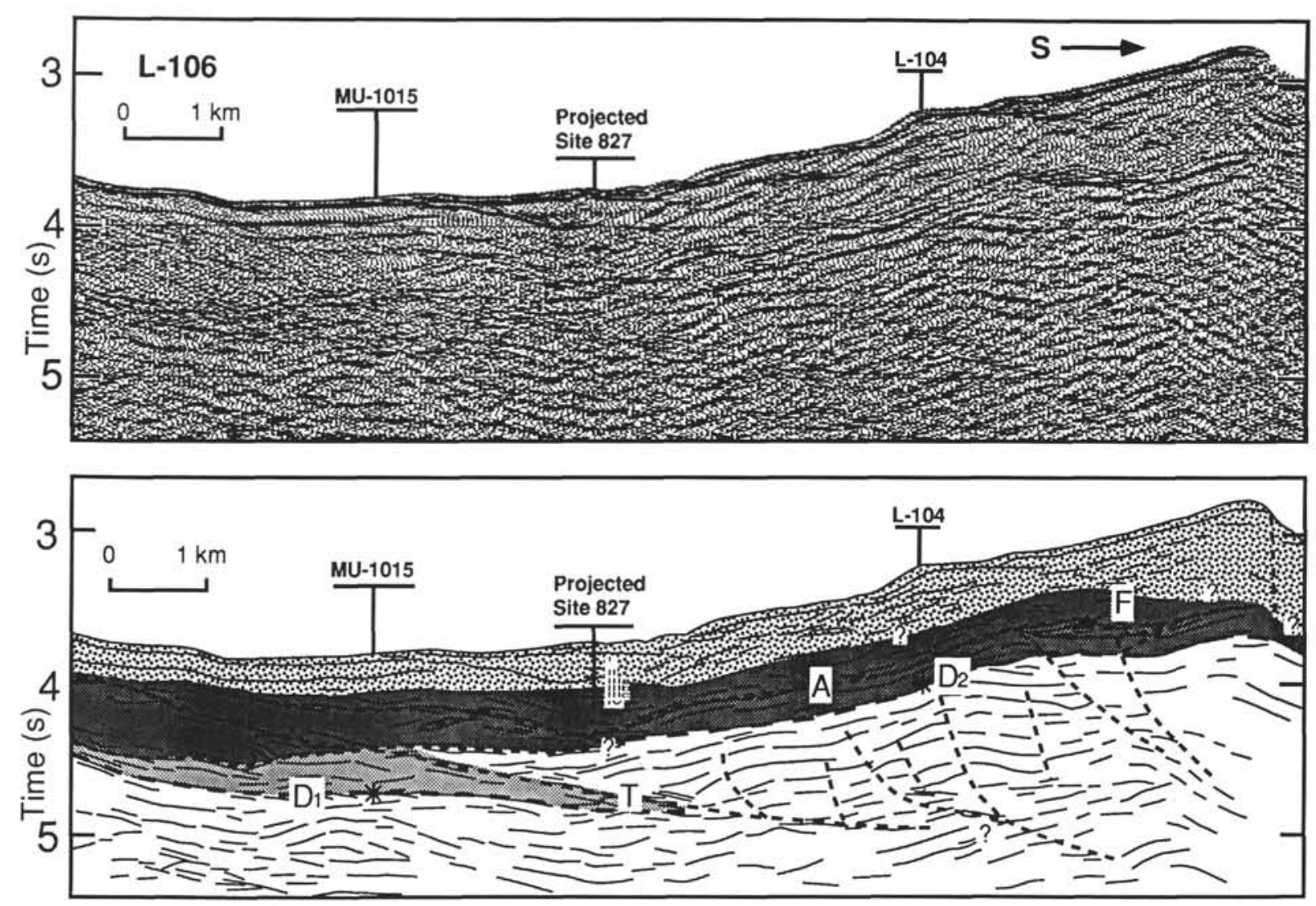

Figure 10. Migrated multichannel seismic reflection data and line drawing for part of section L-106 that cuts along the strike of the accretionary wedge in the collision zone between the NDR and the New Hebrides island arc. For legend see Figure 9 and text.

10) beneath the slope swell suggests that the accreted sequence includes a highly reflective rock body between Reflectors $A$ and $D_{2}$. From crossing Line L-104 we believe that the base of the accreted sequence is marked by Reflector $\mathrm{D}_{2}$. Alternatively, Reflector $\mathrm{D}_{2}$ may outline an unconformity within the subducted ridge crest. The roof of the accreted sequence is not clearly delineated beneath the slope swell along Line L-106. However, the correlation between the zone of incoherent reflections that extends above Reflector A from crossing Line L-104 to Site 827, and accreted sediment recovered in the lower part of Site 827, suggests that the layer above Reflector A includes locally accreted trench-fill deposits (Fig. 10).

\section{Location of the Interplate Décollement}

Seismic reflection and drilling data collected in the NDR-NHIA collision zone provide information helpful in locating the interplate décollement. In the study area, the interplate décollement is not marked by a continuous, strong-amplitude reflector. Beneath the slope terraces, the roof of the buried ridge terrace $\left(D_{1}\right)$ is believed to be the location of the interplate décollement as interpreted solely from seismic reflection Line MU-1015 (Fig. 6). Beneath the slope swell, Reflector $\mathrm{D}_{2}$, which is believed to be the décollement from the interpretation of Line L-104 (Fig.7), is not continuous with Reflector $D_{1}$ (Fig. 10). This deeper reflector appears to merge southward with fault $\mathrm{T}$ and penetrate the ridge crest. Similarly, south-dipping, high-angle faults that deform accreted ridge rocks (Figs. 9 and 10) pierce the subducted ridge crest, indicating that the décollement must lie deeper than $\mathrm{Re}$ flector $\mathrm{D}_{2}$. Other south-dipping, reverse faults pierce the buried northern flank of the ridge (Fisher et al., 1991) implying that the interplate décollement must cut into the ridge deeper than Reflectors $D_{1}$ and $D_{2}$. However, altered fluids with low chloride and high methane concen- trations, typical of décollement in subduction zones (Martin, this volume), were recovered from the lowest thrust faults of Site 829, suggesting that reflector $\mathrm{D}_{2}$, which extends immediately below the terminal depth of the site (Fig. 9), could have properties of the décollement or be connected to it.

In conclusion, the data presented above suggest the presence of two major levels of decoupling: one is represented by Reflectors $D_{1}$ and $\mathrm{D}_{2}$, and the second is inferred to lie deeper within the basement rocks of the NDR. This interpretation would indicate that in addition to frontal accretion of sediment scraped off the ridge along Reflectors $D_{1}$ and $D_{2}$, the ridge is being sheared off and underplated at depth. Alternatively, these observations could suggest an episodic activity of the décollement. For example, when the décollement outlined by Reflectors $D_{1}$ and $D_{2}$ is not active, it may be cut by secondary lowto high-angle faults resulting from progressive stress accumulation or tectonic adjustment. Then, when the décollement becomes active, it cuts the secondary faults and Reflector $\mathrm{D}_{1}$ and $\mathrm{D}_{2}$ become connected.

\section{Formation and Deformation Processes of the Collisional Accretionary Wedge}

Formation of an accretionary wedge depends upon a number of parameters, including the presence on the downgoing plate of material with physical properties suitable for offscraping, the basal friction and dip of the décollement, and the fluid pressures within the accretionary wedge (Davis et al., 1983). However, in a collision zone, the development of a collisional accretionary wedge is more complex than that of a classical accretionary wedge such as in the Nankai (Taira, Hill, Firth, et al., 1991) and Barbados (Mascle, Moore, et al., 1988) subduction zones. The shape of the colliding ridge and the physical properties of its rocks, together with the direction of relative motion 
between arc and ridge influence the processes of accretion and deformation. Physical properties of the ridge sediment are discussed first, and followed by an interpretation of the deformation and thickening processes affecting the NDR-NHIA collisional wedge.

\section{Influence of Physical Properties of Ridge Sediment on the Accretion Style}

Physical properties of the subducting NDR sediment are fundamental parameters in the formation of the thrust sheets that developed in the NDR-NHIA collisional accretionary wedge. Such physical properties include the thickness, density, porosity, and water content of the sediment, and the presence of clay minerals.

The Pleistocene volcanic silt of Unit I of the NDR (Fig. 3) is an unstable sedimentary unit, as indicated by the reverse trend of its density profile, that is the downward decrease from $1.9 \mathrm{~g} / \mathrm{cm}^{3}$ at 10 mbsf to $1.7 \mathrm{~g} / \mathrm{cm}^{3}$ at $61.9 \mathrm{mbsf}$ (Fig. 3; Roperch et al., this volume). This decrease in density correlates with a downward decrease of magnetic susceptibility and a change in the grain size from coarse silt $(38 \mu \mathrm{m})$ and sandy layers in the upper $20 \mathrm{~m}$ of the unit to finer silt $(16-20 \mu \mathrm{m})$ and ash layers in the lower $50 \mathrm{~m}$ of the unit (Reid et al., this volume). Sediment of Unit I is progressively more compacted with depth, and porosity should decrease downhole. However, geotechnical tests (Leonard and Bryan, this volume) indicate that the volcanic silt, overcompacted in the upper part of the unit, is almost normally compacted near 50 mbsf. This difference in compaction agrees with the measured downward increase of porosity from $58.9 \%$ to $67.8 \%$ and water content from $46.6 \%$ to $69.3 \%$ between 4.0 and $51.0 \mathrm{mbsf}$ (Leonard and Ask, this volume; Ask and Leonard, this volume). Therefore, all physical properties presented above suggest that sediment of Unit I is unstable and prone to slide when the ridge is tilted or shaken by earthquakes. Consequently, this sediment is a likely source for the trench-fill deposits. Moreover, when horizontal tectonic stress is added to the overburden stress, the sediment is likely to be sheared preferentially near the base of the unit where the sediment contains more water and is structurally weaker.

The density $\left(1.55-1.65 \mathrm{~g} / \mathrm{cm}^{3}\right)$ of the lower Pliocene ooze of Unit II is lower than that of the overlying volcanic silt, thus contributing to the instability of the sedimentary cover of the ridge. Water content and porosity of the ooze reach values as high as $92.6 \%$ and $72.2 \%$ (Leonard and Ask, this volume), indicating that the unit is an aquifer. These physical properties strongly suggest restricted dewatering and elevated pore pressure in this unit. Hence, the ooze of Unit II appears as a highly permeable and structurally weak layer that is ideal for the propagation of a thrust or proto-décollement. However, no tectonized sediment was observed that would indicate the location of a protodécollement and no fluids were sampled from Unit II to examine fluid flow from the accretionary wedge.

Physical properties are constant within the Oligocene ooze of Unit III but contribute to the overall instability of the ridge sedimentary cover. The density $\left(1.75-1.8 \mathrm{~g} / \mathrm{cm}^{3}\right)$ and acoustic velocity $(1560 \mathrm{~m} / \mathrm{s})$ of Unit III are lower than are those of the overlying volcanic silt of Unit I, and the average water content of Unit III (57.8\%) is slightly greater than that of Unit I (52.6\%). Moreover, the brown clay recovered in the upper Eocene ooze at the base of the unit includes kaolinite (Reid et al., this volume). This clay may also include montmorillonite, which has not been identified from ridge rocks but is in the accretionary wedge. These clay minerals, which are structurally weak, may play an important role in the formation of the décollement (Vrolijk, 1990). However, the composition of pore fluids sampled in the ooze of Unit III indicates that these fluids did not flow from the décollement (Martin, this volume), suggesting that the interplate décollement does not extend as far west as Site 828 through sediment of Unit III.

The volcanic breccia of Unit IV is interpreted as an unconsolidated volcanic breccia or scree deposit, which suggests a poor mechanical coherency within the unit. Although the physical properties of the unit are not known, this poor coherency may provide a weak zone for potential offscraping during the arc-ridge collision.

Site 828 reveals that ridge material that is to be accreted at the deformation front is thin $(100 \mathrm{~m})$. Thrust sheets recovered at Site 829 vary in thickness from 21 to $152 \mathrm{~m}$. These thickness variations can be accounted for by low sediment strength that allows decoupling within ridge sediment, but these variations also depend on tectonic conditions and the amount of slumping on the ridge. For example, slumping of sediment may locally denude a ridge slope and expose a thinner section of older ridge sediment, whereas on a flat or at the trench, slumping results in thickening of trench-fill deposit. Along the lower arc-slope, seismic reflection data suggest that a greater proportion of trench-fill and ridge sediment have been accreted beneath the slope terrace than beneath the slope swell. We interpret this variation from the drilling data and a change of the seismic character of arcslope rocks along the strike of the wedge (MU-1022 in Fig. 9): stronger reflections north of crossing Line L-104 are associated with accreted trench fill and ridge rocks, whereas the nonreflective rock body south of Line L-104 represents more arc-slope deposits. More accreted trench-fill deposits might be related to the fact that the NDR terrace receives more detritus from mass wasting than do the steeper flanks of the ridge crest.

In summary, sediment deposited on the NDR at Site 828 is thin, unstable, and shows distinct intervals with high porosity, low mechanical strength, and high water content. This sediment is prone to mass wasting and may be preferentially sheared off and accreted. These observations account for the thin, primary thrust sheets evident in the accretionary wedge. However, the décollement in the NDRNHIA collision zone is still poorly understood because the décollement was not reached by drilling. Several intervals of ridge sediment appear to be good candidates for the development of the décollement, among which are the lower Pliocene ooze and the clay levels in the upper Eocene ooze. However, we speculate that the proper conditions for the décollement to propagate must be met, at least locally, somewhere at the clay level or within the volcanic breccia because of the presence at Site 829 of accreted slivers of the ridge volcanic breccia, the deepest unit recovered from the ridge.

\section{Deformation Processes of the Collisional Accretionary Wedge}

The three dimensional image of the NDR-NHIA collisional accretionary wedge provided by seismic and drilling data reveals that some structures formed during tectonic accretion, whereas others developed after accretion. The distinction between syn- and post-accretion deformation phases is not clear; as discussed below, however, complex syn-accretion deformation may be related to lateral variation in the basal friction along the décollement, and post-accretion deformation may be caused preferentially by successive impacts of ridgecrest asperities.

Syn- and post-accretion deformations are related to the stress field in the collision zone. The regional compression direction $76^{\circ} \pm 11^{\circ} \mathrm{E}$ (Isacks et al., 1981) at the New Hebrides trench rotated to $33^{\circ} \pm 16^{\circ} \mathrm{E}$ at Site 829 , as suggested by BHTV data (Krammer et al., this volume). This rotation, which may result from the local collision of the $120^{\circ} \mathrm{E}$ trending ridge crest, is in agreement with the $140^{\circ} \mathrm{E}$ strike of the thrust fault traces across the seafloor of the arc terrace (Fig. 2). The $33^{\circ} \pm$ $16^{\circ} \mathrm{E}$ compression direction implies that ridge and trench-fill material is progressively accreted northeastward. The morphology across the ridge induces an increase of the dip of the décollement from about $4^{\circ}$ along the ridge northern terrace to near $12^{\circ}$ along the northern flank of the ridge crest. This increase as well as lithologic and structural heterogeneities of the ridge are possibly responsible for a change in the basal friction of the décollement and for structural variations in the accretionary wedge along-strike the trench. The low-relief imbricate fan that formed beneath the slope terrace indicates low friction 
along the décollement relative to a higher friction at the décollement where underthrusting of the ridge crest has formed a high-relief wedge. We propose that the along-strike transition from low- to highbasal friction, which may be controlled by the ridge morphologic and geologic complexities, generates lateral thrusts or ramps, similarly to those that develop in sandbox experiments performed by Colletta et al. (1991). To simulate development of lateral ramps in thrust systems, these authors introduced a discontinuity in the basal friction. Their model differs from the NDR-NHIA collision zone because the model does not take into account the ridge complexities. However, we use this model as a first-order comparison. In the Colletta et al. (1991) model, the along-strike deformation in the transition zone between the high- and low-friction zones is controlled by a main lateral ramp that roots in the décollement, in the low-friction zone. Major and subsidiary ramps formed and define flake-like rock bodies similar to those that are evident on seismic Lines MU-1022 and L-106. This similarity between analog sandbox model and seismic reflection observations within the NDR-NHIA accretionary wedge suggests that variation of shear stress along-strike of the décollement can account for the development of some of the thrust planes. However, in the sandbox model of Colletta et al. (1991), the development of the lateral ramps is synchronous with the accretionary process and thus cannot explain post-accretion deformation in the NDR-NHIA collision zone.

Post-accretion deformation may result from the subduction of a series of asperities of the ridge crest combined with tectonic adjustments due to progressive stress accumulation and overloading sedimentary process related to mass-wasting. Because of the northward creep of the NDR along the trench and the local $\mathrm{N} 120^{\circ} \mathrm{E}$ trend of the ridge crest, accreted sediment that form the low-relief accretionary wedge is progressively thrust, crushed, and uplifted in front of the moving northeastern flank of the ridge crest. This collision process can account for the development of out-of-sequence thrusts, lowangle or steep reverse faults, and transpressive faults.

\section{CONCLUSIONS}

A low-relief imbricate accretionary wedge has formed where the northern terrace of the NDR summit underthrusts the forearc slope, whereas a high-relief accretionary wedge has developed where the ridge crest collides with the forearc. The resulting collisional accretionary wedge consists of stacks of thin $(28-100 \mathrm{~m})$ thrust sheets formed by frontal accretion of ridge and trench-fill material that appears to have deformed during and after accretion by lateral thrusting, and reverse and strike-slip faulting. The formation of the multiple, thin, primary thrust sheets is related to the thin sedimentary cover on the NDR, the instability of the ridge sediment, and the occurrence of mechanically weak levels with a high water content within this sediment pile. The lateral thrusts interpreted from seismic reflection data delineate thick $(300 \mathrm{~m})$ thrust complexes with a three-dimensional flake-like geometry, which consist of tilted stacks of thin thrust sheets. Local variation of the dip of the décollement and of the basal friction, related to ridge morphologic, structural and lithologic changes, suggests a spatially variable deformation during accretion. This variability is interpreted as one of the causes for the development of lateral ramps and for formation of thrust complexes. However, collisional deformation causes post-accretion reverse and strike-slip faults and out-ofsequence thrust faults to develop as the accretionary wedge accommodates the northward creep of the irregular topography of the ridge crest. As material of the accretionary wedge overrides the ridge crest, scraping off shallow sediment of the ridge, structural deformation tends to develop deeper within the ridge, suggesting that part of the body of the ridge is being sheared off at depth and may be underplated. Underplating of ridge rocks could account for the uplift of Wousi Bank and central Espiritu Santo Island.

\section{ACKNOWLEDGMENTS}

This research was supported by the Institut Français de Recherche Scientifique pour le Développement en Coopération (ORSTOM) and the U.S. Geological Survey. We thank A.J. Crawford, Keith A.W. Crook, and Daniel Orange for their constructive reviews. We are also grateful to the crews of the S.P. Lee and Jean Charcot, and to the technicians of the USGS, Menlo Park, Calif., and the Institut de Physique du Globe, Strasbourg, for their assistance in collecting the multichannel seismic reflection data.

\section{REFERENCES $^{*}$}

Boyer, S.E., and Elliott, D., 1982. Thrust systems. AAPG Bull., 66:1196-1230.

Colletta, B., Letouzey, J., Pinedo, R., Ballard, J.F., and Balé, J.-F., 1991. Computerized X-ray tomography analysis of sandbox models: examples of thin-skinned thrust systems. Geology, 19:1063-1067.

Collot, J.-Y., and Fisher, M.A., 1991. The collision zone between the North d'Entrecasteaux Ridge and the New Hebrides island arc. Part 1: Sea Beam morphology and shallow structure. J. Geophys. Res., 96:4457-4478.

Collot, J.-Y., Greene, H.G., Stokking. L.B., et al., 1992. Proc. ODP, Init. Repts., 134: College Station, TX (Ocean Drilling Program).

Collot, J.-Y., Lallemand, S., Pelletier, B., Eissen, J.-P., Glaçon, G., Fisher, M.A., Greene, H.G., Boulin, J., Daniel, J., and Monzier, M., 1992. Geology of the d'Entrecasteaux-New Hebrides Arc collision zone: results from a deep submersible survey. Tectonophysics, 212:213-241.

Collot, J.-Y., Pelletier, B., Boulin, J., Daniel, J., Eissen, J.P., Fisher, M.A., Greene, H.G., Lallemand, S., and Monzier, M., 1989. Premiers résultats des plongees de la campagnee SUBPSO1 dans la zone de collision des rides d'Entrecasteaux et de l'arc des Nouvelles Hébrides. C. R. Acad. Sci. Ser. 2, 309:1947-1954.

Davis, D.M., Suppe, J., and Dahlen, F.A., 1983. Mechanics of fold-and-thrust belts and accretionary wedges. J. Geophys. Res., 88:1153-1172.

Fisher, M.A., 1986. Tectonic processes at the collision of the d'Entrecasteaux zone and the New Hebrides island arc. J. Geophys. Res., 91:10470-10486. , 1992. Underway geophysics. In Collot, J.-Y., Greene, H.G., Stokking, L.B., et al., Proc. ODP, Init. Repts., 134: College Station, TX (Ocean Drilling Program), 55-63.

Fisher, M.A., Collot, J.-Y., and Geist, E.L., 1991. The collision zone between the North d'Entrecasteaux Ridge and the New Hebrides Island Arc. Part 2: structure from multichannel seismic data. J. Geophys. Res., 96:4479-4495.

Greene, H.G., Collot, J.-Y., Pelletier, B., and Lallemand, S., 1992. Observation of forearc seafloor deformation along the north d'Entrecasteaux RidgeNew Hebrides Island Arc collision zone from Nautile submersible. In Collot, J.-Y., Greene, H.G., Stokking, L.B., et al., Proc. ODP, Init. Repts., 134: College Station, TX (Ocean Drilling Program), 43-53.

Hamilton, E.L., and Bachman, R., 1982. Sound velocity and related properties of marine sediments. J. Acoust. Soc. Am., 72:1891-1904.

Isacks, B.L., Cardwell, R.K., Chatelain, J.L., Barazangi, M., Marthelot, J.-M., Chinn, D., and Louat, R., 1981. Seismicity and tectonics of the central New Hebrides island arc. In Simpson, D.W., and Richards, P.G. (Eds.), Earthquake Prediction: An International Review. Am. Geophys. Union, Maurice Ewing Ser., 4:93-116.

Mascle, A., Moore, J.C., et al., 1988. Proc. ODP, Init. Repts., 110: College Station, TX (Ocean Drilling Program).

Taira, A., Hill, I., Firth, J.V., et al., 1991. Proc. ODP, Init. Repts., 131: College Station, TX (Ocean Drilling Program).

Vrolijk, P., 1990. On the mechanical role of smectite in subduction zones. Geology, 18:703-707.

Abbreviations for names of organizations and publications in ODP reference lists follow
the style given in Chemical Abstracts Service Source Index (published by American
Chemical Society).

Date of initial receipt: 15 April 1993

Date of acceptance: 22 September 1993

Ms 134SR-001 